\title{
Medical emergencies on board commercial airlines: is documentation as expected?
}

\author{
Michael Sand ${ }^{1 *}$, Stephan Morrosch², Daniel Sand ${ }^{3}$, Peter Altmeyer ${ }^{1}$ and Falk G Bechara ${ }^{1}$
}

\begin{abstract}
Introduction: The purpose of this study was to perform a descriptive, content-based analysis on the different forms of documentation for in-flight medical emergencies that are currently provided in the emergency medical kits on board commercial airlines.

Methods: Passenger airlines in the World Airline Directory were contacted between March and May 2011. For each participating airline, sample in-flight medical emergency documentation forms were obtained. All items in the sample documentation forms were subjected to a descriptive analysis and compared to a sample "medical incident report" form published by the International Air Transport Association (IATA).

Results: A total of 1,318 airlines were contacted. Ten airlines agreed to participate in the study and provided a copy of their documentation forms. A descriptive analysis revealed a total of 199 different items, which were summarized into five sub-categories: non-medical data (63), signs and symptoms (68), diagnosis (26), treatment (22) and outcome (20).

Conclusions: The data in this study illustrate a large variation in the documentation of in-flight medical emergencies by different airlines. A higher degree of standardization is preferable to increase the data quality in epidemiologic aeromedical research in the future.
\end{abstract}

\section{Introduction}

Air travel has emerged as one of the most popular, safe and convenient forms of travel. In the past decade, the number of passengers travelling on commercial airlines has increased to almost two billion [1]. Because we live in an aging society, the average age of the passengers who are travelling with chronic disease and the number of chronic diseases per passenger is likely to increase in the future. For the European Union (EU), the EU's statistical analysis unit, Eurostat, has calculated that in the year 2060 over $30 \%$ of the entire EU population will be over the age of 65 . For 2008, Eurostat reported the population over the age of 65 to be $17.1 \%$. However, it is important to keep in mind that these statistics are solely based on age and have no relation to the actual health status of the EU population. Although it is likely that increasing age goes along with chronic diseases, it is not possible to make definite conclusions regarding

\footnotetext{
* Correspondence: michael.sand@ruhr-uni-bochum.de

1 Department of Dermatology, Venereology and Allergology, Ruhr-University Bochum, Gudrunstr. 56, 44791 Bochum, Germany

Full list of author information is available at the end of the article
}

the health status of future travelers around the world based on EU data [2]. Nevertheless, despite the fact that air travel is generally safe, an increase in in-flight medical emergencies is expected [3]. The next generation of aircrafts, such as the Airbus A380-900 (Airbus S.A.S., Toulouse, France) and the Boeing 777 LR (Boeing Commercial Airplanes, Renton, WA, USA), have an estimated cruising range of 15 to $17,000 \mathrm{~km}$ and a maximum passenger load of up to 960 passengers, which will further increase the chances that an in-flight medical emergency will occur during each flight [3].

A recent study reported preliminary evidence that the documentation of in-flight medical emergencies is not as consistent as one would expect. Of the 32 European airlines that were asked to contribute data on in-flight medical emergencies, only four airlines were able to potentially provide the necessary data [4]. In a commentary on the latter study, Ruskin discussed the idea of establishing an international registry of in-flight medical emergencies [5]. Thus, the present study was initiated as a descriptive baseline study to describe the documentation forms that are currently in use. Additionally, the
C Biomed Central 
Table $1 \mathrm{~A}$ total of 1,318 airlines were identified through the World Airline Directory

\begin{tabular}{ll}
\hline Africa & 121 \\
Caribbean & 42 \\
Central America & 15 \\
Central Asia & 38 \\
Europe & 399 \\
Far East & 73 \\
Indian Subcontinent & 58 \\
Middle East & 92 \\
North America & 205 \\
Oceania & 71 \\
South America & 99 \\
South East Asia & 105 \\
\hline
\end{tabular}

data were compared to the recommendations of the International Air Transport Association (IATA), which is the largest airline-representing association worldwide and which has published a sample "medical incident form" in their Medical Manual [6].

\section{Materials and methods}

This study conforms to the applicable local requirements regarding the ethical and investigational committee review, informed consent, and other statutes or regulations regarding the protection of the rights and welfare of the human subjects participating in medical research (http://ClinicalTrials.gov Identifier: NCT01477684, approved by the Ethical Review Board of the Ruhr-University Bochum, Germany, registration number: 409611). This study originates from an academic university hospital. All of the airlines that were listed in the World Airline Directory were contacted and asked to submit a sample of their documentation form for in-flight medical emergencies, provided that confidentiality would be maintained and the airlines' names would not be disclosed [7]. The documentation form data were evaluated independently by two authors (MS and SM) blind to the name and type of airline. The authors reviewed and classified all available data into five sub-categories: non-medical data, signs and symptoms, diagnosis, treatment and outcome. The collected items were compiled into an electronic database (Microsoft Excel for Windows, Microsoft Corp., Redmond, WA, USA). Furthermore, each documentation form was verified for its adherence to the sample "medical incident form" published by IATA in their Medical Manual [6].

\section{Results}

A total of 1,318 airlines were contacted and invited to participate in this study (Table 1). A total of 10 airlines agreed to participate in the study. These airlines were based in Chile, Czechoslovakia, Germany, Switzerland, Turkey, the United Arab Emirates and the United Kingdom. Two hundred items were summarized into five sub-categories: nonmedical data (63), signs and symptoms (68), diagnosis (26), treatment (22) and outcome (20).

The two most frequent items in each sub-category were "date of incidence" and "passenger's name" (nonmedical data), "description of the injury" and "pulse frequency/minute" (signs and symptoms), "convulsive seizures" and "burns" (diagnosis), "application of oxygen" and "resuscitation" (treatment) and "documentation of diversion" and "death of a patient" (outcome). The items "date of incidence" and "passenger's name" were the only items that were documented in all 10 documentation forms described in this study. For exact details, see Tables 2, 3, 4, 5, 6 .

When compared to the sample "medical incident report form" published by the IATA, we found that no airline $(0 / 10)$ included in this study adhered to the latter form.

Table 2 Non-medical data*

\begin{tabular}{|c|c|c|c|c|c|c|c|c|c|c|c|}
\hline Items & Airline & A & B & $\mathrm{C}$ & D & $\mathrm{E}$ & $\mathrm{F}$ & G & $\mathrm{H}$ & 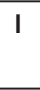 & $\mathrm{J}$ \\
\hline Advice given by a physician/health-care professional ( $\mathrm{Y} / \mathrm{N})$ & & $\mathrm{x}$ & & & & $\mathrm{x}$ & & & & & \\
\hline $\begin{array}{l}\text { Aircraft details } \\
\text { (Type, No. of passengers) }\end{array}$ & & & & & & & & & & & $\mathrm{x}$ \\
\hline Aircraft registration number & & & & & & & & & $\mathrm{x}$ & & \\
\hline Cabin activity & & & & & & & & & & & $x$ \\
\hline Cabin floor condition & & & & & & & & & & & $\mathrm{x}$ \\
\hline Cabin lighting & & & & & & & & & & & $\mathrm{x}$ \\
\hline Communication - ACARS used (Y/N) & & $\mathrm{x}$ & & & & & & & & $\mathrm{x}$ & \\
\hline Communication - High frequency used (Y/N) & & $\mathrm{x}$ & & & & & & & & & \\
\hline Communication - MedLink used (Y/N) & & & & & $\mathrm{X}$ & & & & & & \\
\hline Communication - Satcom used (Y/N) & & $\mathrm{x}$ & & & & & & & & & \\
\hline Date of incident & & $\mathrm{x}$ & $\mathrm{x}$ & $\mathrm{X}$ & $\mathrm{X}$ & $\mathrm{x}$ & $\mathrm{x}$ & $x$ & $x$ & $x$ & $x$ \\
\hline Delay $(\mathrm{Y} / \mathrm{N})$ & & & & & & & & & $x$ & & \\
\hline Departure airport & & $x$ & $x$ & $x$ & & & & & $x$ & & \\
\hline
\end{tabular}


Table 2 Non-medical data* (Continued)

\begin{tabular}{|c|c|c|c|c|c|c|c|c|c|c|}
\hline Destination airport & $\mathrm{X}$ & $\mathrm{X}$ & $\mathrm{x}$ & & & & & $\mathrm{x}$ & $\mathrm{x}$ & $\mathrm{X}$ \\
\hline Doctor on board call (Y/N) & $\mathrm{x}$ & & & & & & & & $\mathrm{x}$ & \\
\hline Duration of occurrence & $\mathrm{x}$ & & & & & & & & & \\
\hline Emergency contact & & & & & $\mathrm{x}$ & & & & & \\
\hline Flight factors & & & & & & & & & & $\mathrm{x}$ \\
\hline Flight number & $\mathrm{X}$ & $\mathrm{X}$ & $\mathrm{X}$ & $\mathrm{X}$ & $\mathrm{X}$ & $\mathrm{X}$ & & $\mathrm{x}$ & $\mathrm{x}$ & $\mathrm{x}$ \\
\hline Flight phase & & & & & & & & & & $\mathrm{x}$ \\
\hline General flight and weather conditions & & & & & & & & $\mathrm{X}$ & & \\
\hline Ground medical control contact (Y/N) & $\mathrm{x}$ & & & $\mathrm{X}$ & & & & & & \\
\hline Ground medical control contact not successful (Y/N) & $\mathrm{x}$ & & & & & & & & & \\
\hline Ground medical control contact successful (Y/N) & $\mathrm{x}$ & & & & & & & & & \\
\hline Health-care professional assistance (Y/N) & $\mathrm{x}$ & & & $\mathrm{x}$ & & & & & $\mathrm{x}$ & $\mathrm{x}$ \\
\hline Liability Information & & & & & $\mathrm{x}$ & & & & & \\
\hline License number of the physician & & $\mathrm{X}$ & & & & & & & & \\
\hline Location of incident & & & & & & & & $\mathrm{x}$ & & \\
\hline Name of the flight purser & $\mathrm{x}$ & $\mathrm{x}$ & $\mathrm{x}$ & & & & & & & \\
\hline Name, address, field of the assisting physician/health-care professional & $\mathrm{x}$ & $\mathrm{X}$ & $\mathrm{x}$ & $\mathrm{x}$ & $\mathrm{x}$ & $\mathrm{x}$ & & $\mathrm{x}$ & $\mathrm{x}$ & $\mathrm{x}$ \\
\hline Passenger's home address & $\mathrm{x}$ & & $\mathrm{x}$ & & $\mathrm{x}$ & & $\mathrm{x}$ & $\mathrm{x}$ & $\mathrm{x}$ & $\mathrm{x}$ \\
\hline Passenger's name & $\mathrm{x}$ & $\mathrm{x}$ & $\mathrm{x}$ & $\mathrm{X}$ & $\mathrm{x}$ & $\mathrm{x}$ & $\mathrm{x}$ & $x$ & $\mathrm{x}$ & $x$ \\
\hline Passenger's age (years) & & & & & $x$ & & & & $x$ & \\
\hline Passenger's date of birth & $x$ & $\mathrm{x}$ & $x$ & $\mathrm{x}$ & & & $\mathrm{x}$ & $x$ & $\mathrm{x}$ & $\mathrm{x}$ \\
\hline Passenger's email address & & $\mathrm{x}$ & & & & & & & & \\
\hline Passenger's frequent flyer status & $x$ & & & & & & & & & \\
\hline Passenger's nationality & & & & & & & $\mathrm{x}$ & & & \\
\hline Passenger's passport number & & & & & & & $\mathrm{x}$ & & & \\
\hline Passenger's seat number & $\mathrm{x}$ & $\mathrm{x}$ & & $\mathrm{x}$ & & & & $\mathrm{x}$ & $\mathrm{x}$ & $\mathrm{x}$ \\
\hline Passenger's sex & $\mathrm{x}$ & $\mathrm{x}$ & & $\mathrm{x}$ & & & & $\mathrm{x}$ & $\mathrm{x}$ & \\
\hline Passenger's signature accepting treatment & & $\mathrm{x}$ & & & & & $\mathrm{x}$ & & & \\
\hline Passenger's signature refusing treatment & & & $\mathrm{x}$ & & & & $\mathrm{x}$ & $x$ & & \\
\hline Passenger's ticket number & & & & & & & & $\mathrm{x}$ & & \\
\hline Passenger's weight & & & & & & & & $x$ & & \\
\hline Passenger's home telephone number & $x$ & $\mathrm{x}$ & & & & & & $x$ & & $x$ \\
\hline Physician on board (Y/N) & $x$ & & & & & & & & $\mathrm{x}$ & \\
\hline Physician compensation offered (Y/N) & & & & $\mathrm{x}$ & & & & & & \\
\hline Physician's email address & & $\mathrm{x}$ & & $\mathrm{x}$ & & & & & & \\
\hline Physician's passport number & & & & & $\mathrm{x}$ & & & & & \\
\hline Physician's telephone number & & $\mathrm{x}$ & & $\mathrm{x}$ & & & & & & \\
\hline Pilot name & & $\mathrm{x}$ & & & & $\mathrm{X}$ & & & & \\
\hline Pilot's personnel number & & $\mathrm{x}$ & & & & & & & & \\
\hline Pilot's signature & & $\mathrm{x}$ & & & & & & & & \\
\hline Port health authority advised (Y/N) & & & & $\mathrm{x}$ & & & & & & \\
\hline Pregnancy $(\mathrm{Y} / \mathrm{N})$ & $x$ & $\mathrm{x}$ & & $\mathrm{x}$ & & & & & & \\
\hline Purser's personnel number & $\mathrm{x}$ & $\mathrm{x}$ & & & & & & & & \\
\hline Purser's signature & & $\mathrm{x}$ & $\mathrm{x}$ & & & & & & & \\
\hline Signature of physician/health-care professional & & $\mathrm{x}$ & $\mathrm{x}$ & & & & & $\mathrm{x}$ & & \\
\hline Time of occurrence & $\mathrm{x}$ & & $\mathrm{x}$ & $\mathrm{x}$ & & & $\mathrm{x}$ & $\mathrm{x}$ & $\mathrm{x}$ & $\mathrm{x}$ \\
\hline Duration of treatment & & & & $\mathrm{x}$ & & & & & & \\
\hline \multicolumn{10}{|l|}{ Type of flooring } & $\mathrm{x}$ \\
\hline \multicolumn{10}{|l|}{ Weather } & $\mathrm{x}$ \\
\hline Witness details (Name/Address/Nationality/Passport No.) & & & & & & & $\mathrm{x}$ & & & $\mathrm{x}$ \\
\hline
\end{tabular}

*Details from 10 airlines (A-J) on the documentation of on board in-flight medical emergencies, sub-category non-medical data. 
Table 3 Signs and symptoms*

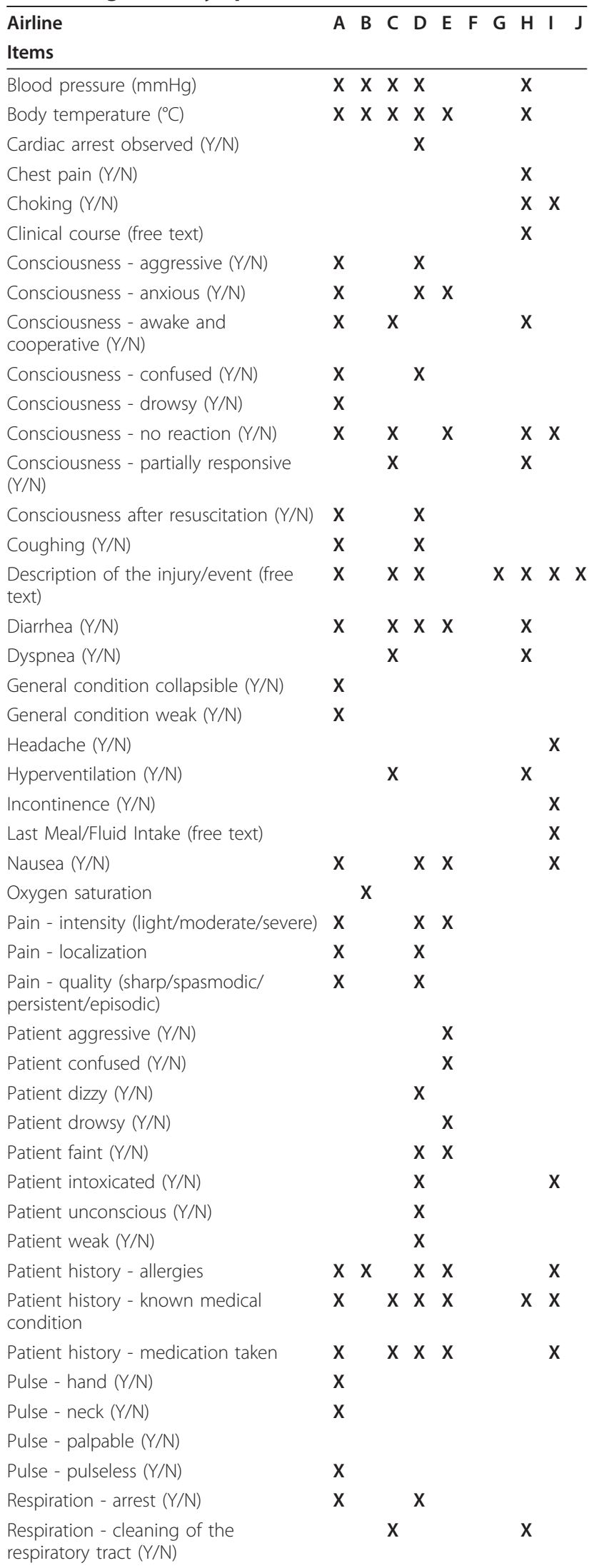

Table 3 Signs and symptoms* (Continued)

\begin{tabular}{|c|c|c|c|c|c|c|}
\hline Respiration - frequency (/min) & $\mathrm{X}$ & $\mathrm{x}$ & $\mathrm{x}$ & $\mathrm{x}$ & $\mathrm{x}$ & $\mathrm{x}$ \\
\hline $\begin{array}{l}\text { Respiration - mouth-to-mouth } \\
\text { ventilation }(\mathrm{Y} / \mathrm{N})\end{array}$ & & $\mathrm{x}$ & & & $\mathrm{x}$ & \\
\hline Respiration - respiratory difficulty $(\mathrm{Y} / \mathrm{N})$ & $\mathrm{x}$ & & & $\mathrm{x}$ & & \\
\hline Respiration - ventilation (Y/N) & & & & & $\mathrm{X}$ & \\
\hline Skin - cold $(\mathrm{Y} / \mathrm{N})$ & $\mathrm{X}$ & $\mathrm{x}$ & $x$ & & $\mathrm{x}$ & \\
\hline Skin - cyanotic (Y/N) & $\mathrm{x}$ & $\mathrm{x}$ & $x$ & & $\mathrm{x}$ & \\
\hline Skin - dry $(\mathrm{Y} / \mathrm{N})$ & & $\mathrm{x}$ & & & $\mathrm{x}$ & \\
\hline Skin - highly reddened (Y/N) & & $\mathrm{X}$ & & & $\mathrm{X}$ & \\
\hline Skin - moist (Y/N) & $\mathrm{X}$ & & $\mathrm{x}$ & $\mathrm{x}$ & $\mathrm{X}$ & $\mathrm{x}$ \\
\hline Skin - normal (Y/N) & & $\mathrm{x}$ & & & $x$ & \\
\hline Skin - pale $(\mathrm{Y} / \mathrm{N})$ & $\mathrm{X}$ & $\mathrm{x}$ & $\mathrm{x}$ & $\mathrm{x}$ & $\mathrm{X}$ & \\
\hline Skin - patchy $(\mathrm{Y} / \mathrm{N})$ & $\mathrm{x}$ & & $x$ & & & \\
\hline Skin - rash $(\mathrm{Y} / \mathrm{N})$ & & & $\mathrm{x}$ & $\mathrm{x}$ & & \\
\hline Skin - rash location & & & $x$ & & & \\
\hline Skin - warm (Y/N) & $\mathrm{X}$ & $\mathrm{X}$ & $\mathrm{x}$ & & $\mathrm{X}$ & \\
\hline Unconsciousness - duration (min) & & & & & & $\mathrm{x}$ \\
\hline Vertigo $(\mathrm{Y} / \mathrm{N})$ & $\mathrm{x}$ & & & & & \\
\hline Vomiting (Y/N) & $\mathrm{x}$ & $x$ & $\mathrm{x}$ & $\mathrm{x}$ & $\mathrm{x}$ & $\mathrm{x}$ \\
\hline Wound location & & & $x$ & & & \\
\hline $\begin{array}{l}\text { Wound severity (mild/moderate/ } \\
\text { severe) }\end{array}$ & & & $\mathrm{x}$ & $\mathrm{x}$ & & \\
\hline
\end{tabular}

*Details from 10 airlines (A-J) on the documentation of on board in-flight medical emergencies, sub-category signs and symptoms.

\section{Discussion}

This study is the first which investigates forms of documentation for in-flight medical emergencies that are currently provided in the emergency medical kits on board commercial airlines. Although we have to keep in mind that the results of this study are not necessarily representative due to selected samples, we were still able to observe a high degree of variance among the forms of documentation that are currently in use by the 10 different airlines in the present study. This is, however, not necessarily the case in other airlines which did not participate in our study.

If airline passengers become ill in the cabin during flight, the majority of airlines carry medical equipment, which enables physicians and medical professionals on board to treat the patient $[8,9]$. Previous studies have shown a help rate of $85 \%$ for all in-flight medical emergencies [4]. According to the recommendations made by the IATA, in-flight medical emergencies should be documented properly for a variety of reasons [6]. The standards and recommendations of the International Civil Aviation Organization (ICAO) also list an "incident record form" as a necessary part of the first aid kit [10]. Furthermore, other authors have also advised proper documentation for the passengers that offer medical assistance during in-flight medical emergencies [11]. The reason for this recommendation is obvious. Although doctors and medical professionals who offer assistance on board an aircraft are covered by the Good 


\section{Table 4 Diagnosis*}

\begin{tabular}{|c|c|c|c|c|c|c|c|c|c|}
\hline $\begin{array}{l}\text { Airline } \\
\text { Items }\end{array}$ & $A$ & B & C & D & $E$ & $F$ & $\mathrm{H}$ & 1 & $J$ \\
\hline Acute abdomen $(\mathrm{Y} / \mathrm{N})$ & & & & & & & $x$ & & \\
\hline Alcohol abuse $(\mathrm{Y} / \mathrm{N})$ & & & & & & & $x$ & & \\
\hline Allergic reaction $(\mathrm{Y} / \mathrm{N})$ & & & & & & & $x$ & & \\
\hline Asthmatic attack (Y/N) & & & $x$ & & & & $x$ & & \\
\hline Bone fracture $(\mathrm{Y} / \mathrm{N})$ & $x$ & & $x$ & & & & $x$ & & \\
\hline Bruising $(\mathrm{Y} / \mathrm{N})$ & $x$ & & $x$ & & & & & & $x$ \\
\hline $\operatorname{Burn}(\mathrm{Y} / \mathrm{N})$ & & & & & & & $x$ & & $x$ \\
\hline Burn $(\mathrm{Y} / \mathrm{N})$ & $\mathbf{x}$ & & $x$ & & & & $\mathrm{X}$ & & $x$ \\
\hline Childbirth (Y/N) & & & & & & & $x$ & & \\
\hline Circulatory collapse (Y/N) & & & $x$ & & & & $x$ & & \\
\hline Convulsive seizure $(\mathrm{Y} / \mathrm{N})$ & $\mathrm{x}$ & & $x$ & $x$ & $\mathrm{x}$ & & $x$ & & \\
\hline Cut $(\mathrm{Y} / \mathrm{N})$ & $\mathrm{x}$ & & & & & & & & $\mathrm{x}$ \\
\hline Febrile convulsion $(\mathrm{Y} / \mathrm{N})$ & & & & & & & $x$ & & \\
\hline Foreign body $(\mathrm{Y} / \mathrm{N})$ & $x$ & & & & & & & & \\
\hline Heart attack $(\mathrm{Y} / \mathrm{N})$ & & & $\mathrm{x}$ & & & & $\mathrm{x}$ & & \\
\hline Hyperglycemia (Y/N) & & & $x$ & & & & $x$ & & \\
\hline Hypertensive crisis $(\mathrm{Y} / \mathrm{N})$ & & & $x$ & & & & $x$ & & \\
\hline Hypoglycemia (Y/N) & & & $x$ & & & & $x$ & & \\
\hline Intoxication (Y/N) & & & & & & & $x$ & & \\
\hline Mental illness (Y/N) & & & & & & & $x$ & & \\
\hline Pseudocroup (Y/N) & & & & & & & $x$ & & \\
\hline Scald $(\mathrm{Y} / \mathrm{N})$ & & & & & & & $x$ & & \\
\hline Sprain $(\mathrm{Y} / \mathrm{N})$ & $\mathrm{x}$ & & & & & & & & $x$ \\
\hline Strain $(\mathrm{Y} / \mathrm{N})$ & & & & & & & & & $x$ \\
\hline Stroke $(\mathrm{Y} / \mathrm{N})$ & & & $\mathrm{x}$ & & & & $\mathrm{x}$ & & \\
\hline Vaginal bleeding $(\mathrm{Y} / \mathrm{N})$ & & & & & & & $x$ & & \\
\hline Wound $(\mathrm{Y} / \mathrm{N})$ & $X$ & & & & & & $x$ & & $x$ \\
\hline
\end{tabular}

*Details from 10 airlines (A-J) on the documentation of on board in-flight medical emergencies, sub-category diagnosis.

Samaritan law, basic documentation, including the patient's symptoms, diagnosis, treatment and administered medication and dosage, is essential in the event of a legal dispute [11]. Similar to any professional medical contact on the ground, documentation of an in-flight medical emergency is not only desirable from a medical standpoint but also from a legal point of view. Furthermore, paramedics and emergency physicians on the ground rely on important medical information and data, which can be secured in writing in-flight and facilitates the initial assessment of the course of an illness from its inception in the air to the point of patient handover. Most importantly, standardized documentation is necessary to facilitate data comparison in an international environment, such as in the aviation and aerospace industry, which includes over 2,000 different airlines worldwide. Each airline should develop its own medical care and incident policy. Without an incident reporting system, no incident management process can be developed. When faced with a patient who requires acute care under special circumstances, such as in flight in an airline cabin, such a process is highly desirable.

Because there is no central registry, some airlines analyze their own events. The majority of passenger transportation airlines, however, are not documenting medical emergencies on board their aircrafts [4]. Because evidence suggests epidemiologic research of in-flight medical emergencies has an important impact on updating recommendations for the contents of emergency medical kits, reassessment of the present situation is necessary [5]. Ruskin has provided strong arguments in favor of a centralized registry of in-flight medical emergencies and states that it would tremendously facilitate the epidemiologic research of in-flight medical emergencies and the development of training materials for physicians preparing to volunteer or assist physicians in evaluating the patients' fitness to fly [5]. Furthermore, a registry would enable the airlines to provide information about the true incidence of specific illnesses that occur during flight because data would not be based on any one single airline.

Based on the results of this study, we believe that it is necessary for the appropriate national and international authorities and organizations to discuss a standardized form of documentation for in-flight medical emergencies. Based on the current data of in-flight medical emergencies and the finding that documentation varies greatly, it is impossible to initiate larger studies with multiple airlines from different regions of the world. The aeromedical community today is dependent on small studies with one or two participating airlines, which document by chance similar items that can be analyzed together. The scientific impact of these studies, however, is low due to limited data quality. Therefore, in the future, we should discuss standardized documentation protocols or an international registry for in-flight medical emergencies.

There are limitations that need to be acknowledged and addressed regarding the present study. The generalizability of the research findings are limited because this study includes only a very small number of participating airlines and there is a high degree of variance due to selected samples.

\section{Conclusion}

The data in this study illustrate a large variation in the documentation of in-flight medical emergencies by 10 different airlines. A higher degree of standardization is preferable to facilitate aeromedical research and to meet the recommendations that are published by the IATA.

\section{Key messages}

- Documentation of in-flight medical emergencies is inadequate due to large variation 
Table 5 Treatment*

\begin{tabular}{|c|c|c|c|c|c|c|c|c|c|c|}
\hline Airline & A & B & $\mathrm{C}$ & D & $\mathrm{E}$ & $\mathrm{F}$ & G & $\mathrm{H}$ & 1 & $J$ \\
\hline Bandage $(\mathrm{Y} / \mathrm{N})$ & & & $x$ & & & & & $x$ & & $x$ \\
\hline Defibrillator used $(\mathrm{Y} / \mathrm{N})$ & $x$ & & $x$ & $x$ & & & & $x$ & $x$ & \\
\hline Defibrillator used (number of times) & $x$ & & $x$ & & & & & & $x$ & \\
\hline ECG monitoring $(\mathrm{Y} / \mathrm{N})$ & & & $x$ & & & & & & & \\
\hline Endotracheal intubation & & & $x$ & & & & & $x$ & & \\
\hline Extra comments on defibrillation & & & $x$ & & & & & & & \\
\hline i.v. line established $(\mathrm{Y} / \mathrm{N})$ & & & $x$ & $x$ & & & & $x$ & & \\
\hline Improvement with oxygen $(\mathrm{Y} / \mathrm{N})$ & $x$ & & & & & & & & & \\
\hline Medical treatment applied (free text) & & & & $x$ & $x$ & & & & $x$ & \\
\hline Medication given on board (Y/N) & $x$ & $x$ & & $x$ & $x$ & & & & & \\
\hline Medication source (patient/medical kit/other passenger) & $x$ & & & & & & & & & \\
\hline Onboard medical equipment/medication used (free text) & & & & $x$ & $x$ & & & $x$ & & \\
\hline Oxygen applied (Y/N) & $x$ & & $x$ & $x$ & $x$ & & & $x$ & $x$ & \\
\hline Problems with the defibrillator & & & $x$ & & & & & & & \\
\hline Pulse palpable after resuscitation ( $\mathrm{Y} / \mathrm{N})$ & $x$ & & & $x$ & & & & & & \\
\hline Resuscitation duration & & $x$ & & & & & & & & \\
\hline Resuscitation performed (Y/N) & $x$ & $x$ & $x$ & $x$ & & & & $x$ & $x$ & \\
\hline Splinting $(Y / N)$ & & & $x$ & & & & & $x$ & & \\
\hline Time of defibrillation & & & $x$ & $x$ & & & & & & \\
\hline Total time of monitoring & & & & $x$ & & & & & & \\
\hline Ventilation after resuscitation ( $\mathrm{Y} / \mathrm{N})$ & $x$ & & & $x$ & & & & & & \\
\hline Wound care $(\mathrm{Y} / \mathrm{N})$ & & & & & & & & $x$ & & \\
\hline
\end{tabular}

*Details from 10 airlines (A-J) on the documentation of on board in-flight medical emergencies, sub-category treatment.

Table 6 Outcome*

$\begin{array}{lllllllllllll}\text { Airline } & \text { A } & \text { B } & \text { C } & \text { D } & \text { E } & \text { F } & \text { G } & \text { H } & \text { I } & \text { J }\end{array}$

Items

Crew fit to operate $(\mathrm{Y} / \mathrm{N})$

$x$

Crew needs Critical Incident Stress Management program (CISM) (Y/N)

Crew uses Critical Incident Stress Management program (CISM) (Y/N)

Description of the outcome (free text)

Diversion $(\mathrm{Y} / \mathrm{N})$

Diversion site

Diversion time

$X$

$X$

$x$

$X$

$\begin{array}{lll}X & x & x \\ X & & x \\ X & & x\end{array}$

$X$

Further treatment - continuation of the flight $(\mathrm{Y} / \mathrm{N})$

Further treatment - in-patient $(\mathrm{Y} / \mathrm{N})$

Further treatment - none $(\mathrm{Y} / \mathrm{N})$

Further treatment - out-patient $(\mathrm{Y} / \mathrm{N})$

Health condition improved $(\mathrm{Y} / \mathrm{N})$

Health condition unchanged $(\mathrm{Y} / \mathrm{N})$

Health condition worsened $(\mathrm{Y} / \mathrm{N})$

Patient deboards with medical help (Y/N)

Patient dies on board $(\mathrm{Y} / \mathrm{N})$

Patient leaves the aircraft on a stretcher $(\mathrm{Y} / \mathrm{N})$

Patient leaves the aircraft in a wheelchair $(\mathrm{Y} / \mathrm{N})$

Patient leaves the aircraft without help $(\mathrm{Y} / \mathrm{N})$

Patient recovered before landing $(\mathrm{Y} / \mathrm{N})$
$X$

$X$

$X$

$X$

$X$

$X$

$X$

$X$

*Details from 10 airlines (A-J) on the documentation of on board in-flight medical emergencies, sub-category outcome. 
- A standardized form of documentation for in-flight medical emergencies is desirable

- A central registry for in-flight medical emergencies will help to facilitate aeromedical research doi:10.1186/cc11238

Cite this article as: Sand et al:: Medical emergencies on board

commercial airlines: is documentation as expected? Critical Care 201216 : R42.

\begin{abstract}
Abbreviations
ACARS: aircraft communications addressing and reporting system; CISM: Critical Incident Stress Management program; EU: European Union; IATA: International Air Transport Association; ICAO: Civil Aviation Organization; mmHg: millimetres of mercury.
\end{abstract}

\section{Acknowledgements}

We thank the participating airlines for their correspondence.

\section{Author details}

${ }^{1}$ Department of Dermatology, Venereology and Allergology, Ruhr-University Bochum, Gudrunstr. 56, 44791 Bochum, Germany. ${ }^{2}$ Department of Anaesthesiology and Intensive Care Medicine, St. Josef Hospital, RuhrUniversity Bochum, Gudrunstr. 56, 44791 Bochum, Germany. ${ }^{3}$ Department of Medicine, Olive View UCLA Medical Center, University of California, Los Angeles (UCLA), 14445 Olive View Drive, Sylmar, CA 91342, USA.

\section{Authors' contributions}

MS participated in the study design, data analysis and interpretation of the data as well as the writing of the manuscript. SM participated in the data analysis. DS participated in the data analysis, literature search, revision of the bibliography, the revision and editing of most of the manuscript. PA participated in the data analysis of the manuscript. FGB participated in the data analysis, the revision and editing of part of the manuscript. MS, SM, DS, PA and FGB critically revised the manuscript for intellectual content. All authors read and approved the final manuscript.

\section{Competing interests}

All authors hereby disclose any commercial associations that may pose or create a conflict of interest with the information presented in this manuscript. The authors report no conflicts of interest. The authors alone are responsible for the content and writing of the paper.

Received: 11 August 2011 Revised: 25 January 2012

Accepted: 7 March 2012 Published: 7 March 2012

\section{References}

1. Medical Guidelines Task Force AMA: Medical guidelines for airline travel. Aviat Space Environ Med , 2 2003, 74:A1[http://www.asma.org].

2. European Commission: Eurostat: Your key to European statistics.[http:// epp.eurostat.ec.europa.eu/portal/page/portal/population/data/main_tables].

3. Gabel A: Kardiologische Notfälle an Bord von Verkehrsflugzeugen. Notfall + Rettungsmedizin 2011, 14:305-322

4. Sand M, Bechara FG, Sand D, Mann B: Surgical and medical emergencies on board European aircraft: a retrospective study of 10189 cases. Crit Care 2009, 13:R3.

5. Ruskin KJ: In-flight medical emergencies: time for a registry? Crit Care 2009, 13:121.

6. International Air Transport Association: Montreal-Geneva. Medical Manual., 366-67[http://www.iata.org/medical-manual], Appendix D.

7. AIU Airline Update.com World Airlines Directory. [http://www. airlineupdate.com/content_public/airlines/country_index.htm].

8. Sand M, Gambichler T, Sand D, Thrandorf C, Altmeyer P, Bechara FG: Emergency medical kits on board commercial aircraft: a comparative study. Travel Med Infect Dis 2010, 8:388-394.

9. Sand M, Bechara FG, Sand D, Mann B: In-flight medical emergencies. Lancet 2009, 374:1062-1063.

10. International Civil Aviation Organisation: Annex 6, Operation of Aircraft Part I, International Commercial Air Transport, Aeroplanes, Chapter 6 Aeroplane Instruments, Equipment and Flight Documents attachment B. First Aid Medical supplies.4.

11. Gendreau MA, DeJohn CA: Responding to medical events during commercial airline flights. N Engl J Med 2002, 346:1067-1073.

\section{Submit your next manuscript to BioMed Central and take full advantage of:}

- Convenient online submission

- Thorough peer review

- No space constraints or color figure charges

- Immediate publication on acceptance

- Inclusion in PubMed, CAS, Scopus and Google Scholar

- Research which is freely available for redistribution

Submit your manuscript at www.biomedcentral.com/submit
C Biomed Central 